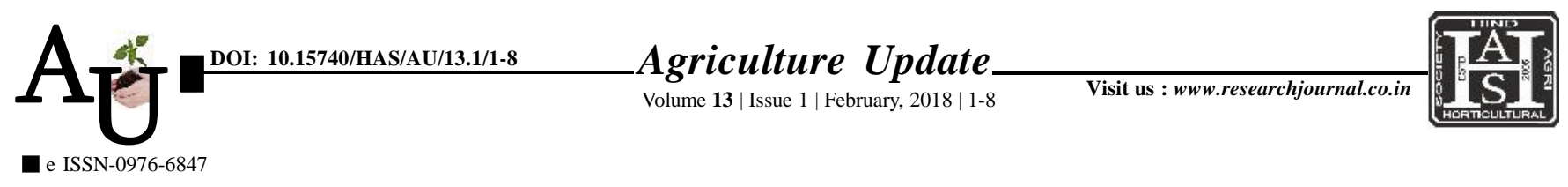

\title{
Research Article: Impact of entrepreneurship development programmes in North Karnataka
}

\section{Geeta P. Channal and K.V. Natikar}

Article Chronicle:

Received :

18.04.2017;

Revised :

01.12.2017;

Accepted :

15.12.2017

KeY WoRds :

Entrepreneur,

Entrepreneurship,

Entrepreneurship

development

programme (EDP),

RUDSETI, Impact,

Leadership, Decision

Making, Confidence,

Management

orientation,

Establishment of

enterprise, Growth/

Expansion of

enterprise

Author for correspondence :

\section{Geeta P. Channal}

Department of

Agricultural Extension

Education, College of

Agriculture, University

of Agricultural Sciences,

Dharwad (Karnataka)

India

Email:geetrajpatil@

yahoo.co.in

See end of the article for

authors' affiliations
SUMMARY : The present study was undertaken during the year 2014-15 in three districts of North Karnataka. Fifty trained and 50 untrained entrepreneurs from each district were selected making a total sample size of 300. Majority of the trained and untrained were from middle age group, had education upto middle level of schooling, coming from rural area and having nuclear families.

How to cite this article : Channal, Geeta P. and Natikar, K.V. (2018). Impact of entrepreneurship development programmes in North Karnataka. Agric. Update, 13(1): 1-8; DOI : 10.15740/HAS/AU/13.1/1-8. 